\title{
USING ONLINE COLLABORATION FOR DEVELOPING EFL PREPARATORY STAGE STUDENTS' READING AND WRITING SKILLS AND THEIR MOTIVATION FOR LANGUAGE LEARNING
}

\author{
Mohammed Khalaf Ismail Makhlouf
}

English Teacher at Al-Azher Al-Sharif

\section{Abstract}

This study aimed at investigating using online collaboration for developing EFL preparatory stage students' reading and writing skills and their motivation for language learning. Four Instruments in the study were developed a reading and writing skills inventory to determine the reading and writing skills necessary for the students, a reading and writing skills test, a motivation scale for language learning and a rubric for reading and writing skills. The participants were two classes (64 students) from the second year preparatory school at Somoha Al Azhar Institute in Alexandria. They were divided into two groups. A pre-test, a post -test and a motivation scale were administrated. The study was based on action research design. The selected target reading and writing skills were integrated on Wiki forming an online reading and writing course. The selected reading and writing skills were summarizing, paraphrasing, suggesting and end for a short story. Findings of the study indicated significant differences between the mean scores of the experimental group and those of the control group on the post reading and writing test, post administration of the motivation scale towards learning language in favour of the experimental group. The results showed that online collaboration seemed to enhance the students' reading and writing skills. This study recommends using online collaboration as a tool in teaching reading and writing skills.

Keywords: Online collaboration, reading and writing skills and motivation.

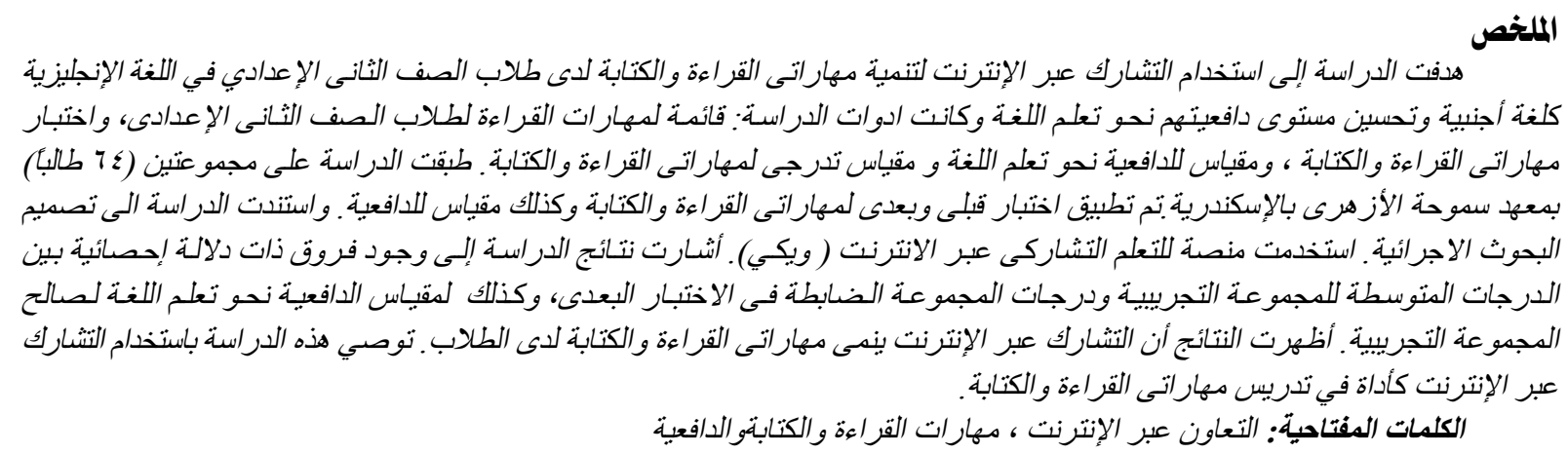

\section{Introduction:}

Reading and Writing are the most important base for learning. Reading is the way to receive others' thoughts and beliefs and Writing is a way of expressing opinions, ideas, and thoughts. As the world is changing every day and new technologies have changed methods of reading and writing, there is a need to search for new ways that motivate students for further learning and coping with the new communication and information technology.

\section{Jackendoff (2003) indicates that} reading and writing provide students with rudimentary literacy skills as there is a positive relationship between reading and writing on developing both of them. Thus, students can gain the maximum benefit 
from the inter-dependent nature of reading and writing skills such as reading to write about the main idea in their own words and having a good model for the organization.

According to Cooper and Kiger (2009), reading and writing are the easiest ways to face future learning problems as reading gives students the information which enables them to know the best ways for writing so teachers should provide students with sufficient amount of reading to help them to build their writing. Moreover, he added that reading includes many sub-skills, such as vocabulary, spelling, getting meanings and understanding how others think, many subskills which could help improve readingwriting skills, such as summarizing, responding to a letter and paraphrasing.

In order to achieve success in learning English, learners of English need something to drive them to start and pursue learning. One basic factor which has been playing a great role while learners are studying English is motivation.

Küçük (2007)assures that factors motivating students to become involved in reading and writing activities include higher order thinking, exploration and observation skills, knowledge, a regular habits of reading and writing, innovativeness, a critical eye for things happening around, richness of emotions and experience, sufficient use of information, communication technologies, and diversity of methods .
Raguseo (2009) reports that since motivation is the key concept in the learning process and most of the learning theories emphasized the importance of motivation, so the teachers' role to integrate technology that could create a motivating learning environment.

Technology has changed the processes, products, and contexts for literacy in dramatic ways. Mackey (2007) reported that with the advent of the internet, computer technology is affording students the opportunity to become more creative in their reading, writing, and individual expression. Moreover, he asserted that the use of wikis and blogs can facilitate the process of students actively engaging in the collaborative process to allow students to work together to achieve common goals and objectives using the computer to share knowledge where everyone benefits.

Dawson (2008) mentions some benefits to learning and teaching using Web 2.0. It is a participatory, collaborative, creative ethos of inquiry. These benefits can be summed up as follows:

- It stimulates new modes of inquiry;

- It engages students in collaborative learning activities;

- It helps students engage with new literacies;

- It facilitates online publication of content; and

- It has a positive impact on motivation. 


\section{Context of the problem}

In today's rapidly changing world, reading and writing are viewed as important keys to successful communication, especially after the great developments achieved in all fields of life. In general, reading and writing are powerful skills for achieving high grades of success.

Giesen (2001) confirms that reading and writing are so closely linked so they mutually reinforce each other and promote learning when they are integrated into classroom activities. Further, she added that their integration allows for multiple approaches to tasks, covering all learning styles as students become better readers, writers, and thinkers when they learn reading and writing together.

Sutter (2007) in his part mentions that integrating reading and writing in one teaching strategy through guided reading books. She stated that this integration helped in solving a lot of problems as reading could provide a good model for writing. Durukan (2011) investigated cooperative integrated reading and writing. He found that students receiving integrated instruction outperformed the students receiving traditional instruction. Elmashary (2013) aimed to develop students' critical reading and writing skill using students' experience in reading. The study provided evidence that success in reaching a higher level of reading depends on the students' ability to relate new information to their background knowledge to find answers to cognitive questions (schema). Then, they were asked to use this information in written work. Kemper and Meyer (2015), on their part, assert the importance of integrating reading and writing skills. They considered reading as a good way for writing as reading provides a good model for well- written text. Good writers know how much reading helps them to write well. They added that there are a lot of strategies that students can benefit from their reading into writing such as summarizing a text and using graphics to arrange reading's ideas to use in writing.

In addition to all previously reviewed studies that proved the importance of integrating reading and writing, other studies proved that reading and writing are still challenging tasks for students. There are many reasons for these challenges. In English as a foreign language, EFL learners view reading and writing as boring skills, which could affect their academic performance negatively and, thereby, reduce the students' ability to read and write appropriately.

Chen (2006) reveals that there are some problems related to reading and writing. Students cannot get the main idea to write about it, neither can they understand what lies behind the passage. Moreover, students are not able to write a well-organized topic and cannot express themselves freely. 
On the other hand, there are some problems related to the teaching strategy. Gallagher (2006) proposes that adopting a regular strategy in teaching reading and writing is a real problem. He adds that teachers tell students that reading and writing are worthwhile. They are put into pressure writing situations where their efforts will be scrutinized and graded. When they finish the task, they are grateful that it is over and hope not to answer a reading comprehension passage or to write again anytime soon.

Shelly, Frydenberg, and Marshal (2015) assert that the teaching strategy is the first and foremost issue worth probing into. Typically, teaching is based on a prescribed textbook. Most teachers simply stick to the textbook and adopt a very traditional method in their teaching. A typical reading and composition lesson starts with teaching the class a sample of reading comprehension and writing, which usually consists of several sentences describing a person or an object. Then, with the help of guiding questions, the teacher asks the students to give parallel writing, which means to write a similar text by changing names, pronouns or some details through this way or to answer some reading questions related to similarity. So, the present research suggests that the teacher should break down the negativity of students and search for new methods, which could make students interested in the task of reading and writing.
According to the previous studies that showed a problem in reading and writing skills, the present researcher suggested teaching reading and writing as integrated skills. To support this proposition, the present researcher investigated the literature related to integrating reading and writing and revealed that many researchers attempted to create such integration in different ways.

Recent research asserts readingwriting connections in the language classroom. In this respect, Tsai (2006) confirms the importance of connecting reading and writing into the classroom activities avoiding teaching reading and writing separately. Tsai added that teaching reading and writing together is not a difficult challenge but teachers should be careful to design teaching practice that is purposeful. Teaching reading and writing separately makes students see reading as a process of coding and writing as a context for using grammar. Through reading and writing connection, however, students can be reflective readers and writers who are capable of communicating in real-life situations.

Motivation is a basic factor in the success of learning process, so Guilloteaux and Dörnyei (2008) assert that teachers should understand the nature and quality of learner motivation and how to create motivating environment to help learners achieve their goals. 
Bunn (2011) States that integrating reading and writing improves student learning in all disciplines. It makes students more motivated and actively engaged in what they are studying. With this engagement comes greater academic success and that in turn increases student motivation to learn reading and writing particularly and learning the language in general.

According to Hidi and Boscolok (2007), the major contribution towards understanding student's lack of motivation to read and write come from approaches that show the complexity of reading and writing processes. Bahous, Bacha, and Nabhani (2011) studied the difficulties of many EFL learners' experience in reading and writing English. Results of their exploratory investigation of the perceptions of EFL learners through interviews and surveys uncovered problems related to motivation that used to prevent the learner from reading and writing in English. The results of the study indicated that learners are less motivated to learn English because of an over-focus on reading and writing skills with limited learning experiences, boring materials, and unclear relationships between reading and writing.

The present researcher believes that there is a problem concerning students' motivation. Motivating EFL students to develop reading and writing skills is quite complex.
It has been noticed that living in a digital age implies searching for new methods of teaching reading and writing skills that make students involved in the process of learning. As the current researcher had courses in Wikis and blogs, he presumes that popular applications of elearning such as weblogs and wikis could serve as a valuable tool for improving reading and writing skills in the EFL classroom. A collaborative website is a web page that can be viewed and modified by any online person who has a user name and a password. In other words, any person can change the content. Moreover, Wikis and blogs permit group collaboration across the Internet and provide users with both author and editor functions. To confirm this assumption, the present researcher reviewed literature related to online collaboration and found that. Fritz (2005) mentions that students achieved learning outcomes while using handheld computers. The students learned content through collaboration with peers. $\mathrm{He}$ maintained this collaborative learning helped the students learn content and communicative skills at a time.

With some ingenuity and creativity, the uses of collaborative websites in education could be very beneficial, Duffy and Bruns(2006) list several possible educational uses of Wikis as follows:

- students can add summaries of their thoughts from the prescribed reading, building a collaborative bibliography on a wiki. 
- for publishing course resources like syllabi, and handouts and students can edit and comment on these directly for all to see.

- Wikis as a knowledge base to enable teachers to share reflections and thoughts regarding teaching practices, and allowing for versioning and documentation.

- Wikis are useful for brainstorming, and editing a given wiki topic can produce a linked network of resources.

Accordingly, it has been made clear that EFL Preparatory are not motivated enough to engage in learning the course content. As a teacher, the researcher attempted to design assignments that could develop students' reading and writing skills and motivate them to be engaged in the learning process.

\section{Pilot Study}

In order to identify the EFL second-grade preparatory stage students' reading and writing skills, the researcher conducted a pilot study through administrating an integrated reading and writing test. Participants were 30 preparatory stage students. The test aimed at assessing students' reading and writing skills. Students were asked to find the main ideas, to write an appropriate end after reading a short story and to read a text and summarize it. Moreover, the researcher interviewed students to know about their motivation for reading and writing skills and if they would like to use the internet in learning English.

In addition, The researcher interviewed a number of teachers $(n=15)$ to find out about their strategy-use in teaching reading and writing. Teachers were asked if they would rather integrate reading and writing skills and if they ever tried to use the internet to teach English to motivate their students. The results of the pilot study revealed that:

Table (1) students performance on the reading and writing skills test.

\begin{tabular}{|c|c|c|c|c|c|}
\hline Skills & $\mathbf{N}$ & Minimum & Maximum & Mean & $\begin{array}{c}\text { Std. } \\
\text { Deviation }\end{array}$ \\
\hline Main idea & 30 & .00 & 5.00 & 2.33 & 1.34 \\
\hline Summarizing & 30 & .00 & 6.00 & 2.0 & 1.53 \\
\hline $\begin{array}{l}\text { suggesting } \\
\text { an end for a } \\
\text { short story }\end{array}$ & 30 & .00 & 6.00 & 2.36 & 1.67 \\
\hline Earned mark & 30 & 1.00 & 16.00 & 6.70 & 4.23 \\
\hline
\end{tabular}

Results of table (3) reveals that there is a weakness in second-year preparatory stage students' reading and writing skills. Clearly, there is a need for developing second-year preparatory stage students' reading and writing skills.

- The results of interviewing students showed that they had no interest in reading and writing skills due to having no choice for topics which they read and write about, they did not 
participate with the teacher as he took the leading role in teaching. They also showed a great interest to learn using the internet.

- From the other side, the results of interviewing teachers indicated that 12 teachers $(=80 \%)$ pointed out that they used one step of bottom-up strategy which aimed at explaining the meaning of each word and $3(=20 \%)$ teachers pointed out that they use different strategies to teach reading and writing. All teachers showed that they taught reading and writing separately and never tried to use the internet in learning English.

- As a senior teacher of EFL, the research observed that much did not integrate reading and writing skills. Teachers used outdated strategies such as translating the words into Arabic and depending upon similar words between the question and a reading passage to answer the questions. These strategies do not involve students in collaborative tasks or drive them to use the ICT technologies to learn better. Consequently, there is an urgent need for alternative strategies that could help the students to read and write more successfully. using online collaboration as a medium that could contribute to developing preparatorystage students' reading-writing skills as well as their motivation for language learning.

\section{Problem of the Study}

In the light of researcher's experience as a teacher for 15 years, the review related studies and the results of the pilot study, it has been found that generally little attention has been paid to reading and writing in EFL classrooms and that they are hardly taught as integrated skills. Activities that entailed reading-writing integration such as writing in response to reading texts, summarizing and reading for answering specific questions were under evaluated. Furthermore, students struggled with some particular skills such as getting the main idea/ ideas of a text, identifying specific ideas, presenting information related to a text/story, posing questions to paragraph, text or a picture and Suggesting alternative ideas and titles, for a text. This lack of reading and writing skills made students uninterested, unenthusiastic and demotivated to read and write well. Therefore, the main concern of the present study is to investigate how far using online collaboration could possibly promote EFL $2^{\text {nd }}$ grade preparatory stage students' reading and writing skills, and enhance their motivation for language learning.

Based on the previous problem statement, the researcher proposes that teaching integrated reading and writing skills call for adapting technologies such as Blogs and Wikis as a collaborative medium that may improve their learning and enhance their motivation. 


\section{Questions:}

The present study attempts to answer the following main question:

How could online collaboration contribute in developing the 2 nd year prep stage students' reading-writing skills and enhancing their motivation for language learning?"

From the previous question, the following questions branch out:

a. What are the reading-writing skills required for the EFL second-year preparatory stage students?

b. How far could using online collaboration improve the students' reading and writing skills?

c. How far could online collaboration improve students' motivation for language learning?

\section{Hypotheses:}

Based on the questions of the study the following hypotheses are formulated

1. There is no statistically significant difference between the mean score of the participants of the experimental group and those of the control group on the reading and writing skills pretest.

2. There is no statistically significant difference at the 0.5 level between the mean score of the participants of the experimental group and those of the control group on the preadministration of motivation scale.
3. There is a statistically significant difference between the mean score of the participants of the experimental group and those of the control group on the reading and writing skills posttest in favor of the experimental group.

4. There is a statistically significant difference between the mean scores of the participants of the experimental group on the pre and Postadministration of reading and writing skills test in favor of Postadministration.

5. There is a statistically significant difference between the mean score of the participants of the experimental group and those of the control group on the post- administration of motivation scale in favor of the experimental group.

\section{Purpose:}

The present study aims at investigating how far using online collaboration contribute in developing the reading and writing skills of EFL preparatory stage students' and enhancing their motivation for language learning

\section{Significance:}

The study may be significant because it could:

1. help raise students' awareness of the importance of using new technology in learning the English language; 
2. help students improve their reading and writing skills through more authentic and interactive learning environments.

3. provide EFL teachers with new strategies for teaching reading and writing

4. motivate students for language learning.

5. provide curriculum developers with alternative technology-based solutions that might help them design more authentic and responsive instructional media, strategies and curriculum.

\section{Delimitations:}

The study will be confined to:

- Wiki as a collaborative website

- $2^{\text {nd }}$-year preparatory school students at Somoha Al-Azhar institute, Alexandria Governorate.

- Reading and writing skills appropriate for second-grade preparatory stage students.

\section{Definition of terms:}

\section{Online collaboration}

Reborts (2004) defined collaboration as working together as students to discuss all parts of assignments, adding and changing things in conjunction with one another as they come to understand more about the topic at the end, and the final product is truly a group product.
Yang (2013) defined online collaboration as a coordinated, synchronous activity that is the result of an ongoing attempt to construct and maintain a shared conception of a problem as it includes thinking skills discussion and consideration of ideas and social skills development.

online collaboration is operationally defined as "the medium where students can participate in shared EFL activities online through idea sharing and collaborating to accomplish a common learning goal which is developing reading and writing skills."

\section{Integrated Reading and Writing}

Oxford (2001) defined integrated reading and writing as learning to read and write in a highly integrated, natural, and communicative fashion.

Shanahan (2000, cited in Cho \& Brutt-Griffler, 2015) elaborated on integrated reading and writing as learning shared knowledge that readers and writers use through reading-writing connections. It includes "metaknowledge" (knowing about the functions of reading and writing), "domain knowledge" (prior knowledge about substance and content), "knowledge about universal attributes" (knowing about letter recognition and grammar or rules for sentence construction), and "procedural knowledge and skill to negotiate reading and writing" (predicting, questioning, recalling, and trying to find analogies). 
The researcher can operationally define integrated reading and writing skills as "Skills of learning how to read and write simultaneously in collaborative online activities, where reading could improve writing and vice versa; namely, while students learn how to write topic sentences, they also learn how to read a paragraph for identifying main ideas and thesis statement.

\section{Motivation}

Denhart and Aristigueta (2009, p. 147) defined motivation as the combination between a person's desire and energy directed at achieving a goal. Furthermore, motivation can be intrinsic, such as satisfaction and feelings of achievement; or extrinsic, such as rewards, punishment, and goal obtainment. Not all people are motivated by the same things and over time their motivators might change.

The researcher can define motivation for language learning operationally as "the great desire that activates, directs, and sustains students' learning and participation in EFL activities"

\section{Results of the study}

\section{Results of the First Hypothesis}

The first hypothesis stated that: there is no statistically significant difference between the mean score of the participants of experimental group and those of the control group on the pretest of overall reading and writing skills. In order to verify this hypothesis, the researcher used the t-test. Table (2) below shows these differences.

Table (2) Equivalence of the two groups on the pre-administration of reading and writing skills test

\begin{tabular}{|c|c|c|c|c|c|c|}
\hline \multirow{2}{*}{ Skills } & \multicolumn{2}{|c|}{ experimental group } & \multicolumn{2}{|c|}{ control group } & \multirow{2}{*}{ T-value } & \multirow{2}{*}{ Sign. } \\
\cline { 2 - 5 } & mean & Std. Devi. & mean & Std.Devi & & \\
\hline summarizing & 6.25 & 2.56 & 6.15 & 2.42 & 0.15 & No Sig. \\
\hline paraphrasing & 5.72 & 2.95 & 5.91 & 2.36 & 0.28 & No Sig. \\
\hline $\begin{array}{c}\text { Writing an end for } \\
\text { short story }\end{array}$ & 6.81 & 3.07 & 6.53 & 2.24 & 0.41 & No Sig. \\
\hline Total & 18.78 & 8.28 & 18.59 & 6.84 & 0.09 & No Sig. \\
\hline
\end{tabular}

Results in Table (1) reveal that there is no statistically significant difference between the mean scores of the experimental group and those of the control group on the pre test of reading and writing skills. These results point to the equivalence of the two groups before implementing the treatment.

\section{Results of the Second Hypothesis}

The second hypothesis stated that: There is no statistically significant 
difference between the mean scores of the participants of experimental group and those of the control group on the preapplication of motivation scale. In order to verify this hypothesis, the researcher used the t-test. Table (8) below shows these differences.

Table (3) Establishing the equivalence of the two groups on the pre-administration of the motivation scale

\begin{tabular}{|c|c|c|c|c|c|c|}
\hline \multirow{2}{*}{ Variable } & \multicolumn{2}{|c|}{ experimental group } & \multicolumn{2}{|c|}{ control group } & \multirow{2}{*}{ T-value } & \multirow{2}{*}{ Sign. } \\
\cline { 2 - 5 } & Mean & Std. Devi. & mean & Std. Devi. & & \\
\hline motivation & 56.6 & 3.63 & 58.0 & 3.21 & 1.64 & No Sig. \\
\hline
\end{tabular}

Results in Table (3) reveals that there is no statistically significant difference between the mean scores of the experimental group and those of the control group on the pre administration of motivation scale. The mean scores are 56.6 and 58.0 respectively and $t$ value is 1.64 . These results mean that the two groups had almost the same level of motivation at the beginning of the study.

\section{Results of the Third Hypothesis}

The third hypothesis stated that: There is a statistically significant difference between the mean score of the participants of experimental group and those of the control group on the posttest of overall reading and writing skills in favor of experimental group. In order to verify this hypothesis, the researcher used the t-test. Table (3) below compare the reading and writing performance of the two groups on the post administration.

Table (4) Compering the reading and writing performance of the two groups on the post administration

\begin{tabular}{|l|l|l|l|l|l|l|}
\hline \multirow{2}{*}{ Skills } & \multicolumn{2}{|c|}{ experimental group } & \multicolumn{2}{c|}{ control group } & \multirow{2}{*}{ T-value } & \multirow{2}{*}{ Sign. } \\
\cline { 2 - 7 } & Mean & Std. Devi. & mean & Std. Devi. & & \\
\hline summarizing & 12.59 & 3.59 & 6.93 & 2.12 & 7.67 & 0.001 \\
\hline paraphrasing & 12.13 & 3.69 & 5.78 & 1.99 & 8.54 & 0.001 \\
\hline Writing an end for short story & 12.78 & 3.64 & 6.68 & 2.16 & 8.13 & 0.001 \\
\hline Total & 37.50 & 10.84 & 19.41 & 6.11 & 8.22 & 0.001 \\
\hline
\end{tabular}

According to Table (4), there is a statistically significant difference between the mean score of the participants of experimental group and those of the control group at 0.001 level on the posttest of overall reading and writing skills in favor of experimental group. Statistics show that the mean score of the experimental group was 37.5 compared to that of the control group $(\mathrm{m}=19.41)$. In 
addition, the experimental group outperformed than the control group in all these skills.

\section{Results of the Fourth Hypothesis}

The fourth hypothesis stated that: there is a statistically significant difference between the mean scores of the participants of experimental group on the pre and Post-administration of overall reading and writing skills in favor of Postadministration. In order to verify this hypothesis, the researcher used the t-test. Table (5) below compare the reading and writing performance of the experimental group on the pre- post administration.

Table (5) Compering the reading and writing performance of the experimental group on the pre- post administration.

\begin{tabular}{|l|c|c|c|c|c|c|c|}
\hline \multirow{2}{*}{ Skills } & \multicolumn{2}{|c|}{$\begin{array}{c}\text { experimental } \\
\text { group Pre }\end{array}$} & \multicolumn{2}{c|}{$\begin{array}{c}\text { experimental } \\
\text { group Post }\end{array}$} & $\begin{array}{c}\text { T- } \\
\text { value }\end{array}$ & Sign. & Eta2 \\
\cline { 2 - 6 } & mean & Std. Devi. & mean & Std. Devi. & & & \\
\hline Summarizing & 6.25 & 2.56 & 12.59 & 3.59 & 17.71 & 0.001 & 0.91 \\
\hline Paraphrasing & 5.71 & 2.95 & 12.12 & 3.69 & 15.13 & 0.001 & 0.88 \\
\hline $\begin{array}{l}\text { Writing an end for } \\
\text { short story }\end{array}$ & 6.81 & 3.07 & 12.78 & 3.64 & 15.61 & 0.001 & 0.89 \\
\hline Total & 18.78 & 8.28 & 37.50 & 10.84 & 17.53 & 0.001 & 0.91 \\
\hline
\end{tabular}

According to Table (5) illustrates that there is a statistically significant difference between the mean score of the participants of experimental group on the pre and Postadministration at 0.001 level of overall reading and writing skills in favor of Postadministration. A close look at the table reveals that The mean scores are 18.7 and 37.5 and $t$ value is 17.5 . These results mean that the experimental group is outperformed in post adiminstration in reading and writing test compared to the pre administration.

In order to determine the effect size of the program on the reading and writing performance of the experimental group, the eta squared ( $\eta 2)$ test was used.
Results indicated a large effect of the program on the experimental group performance in individual skills (eta2 $=0.91,0.88,0.89$ respectively) used in the overall test score $($ eta2 $=0.9$ )

\section{Analysis of the Fifth Hypothesis Results}

The fifth hypothesis stated that: There is a statistically significant difference between the mean scores of the participants of experimental group on the pre and Post-administration of motivation scale in favor of Post-administration. In order to verify this hypothesis, the researcher used the t-test. Table (5) below compare the motivation scale results of the experimental group on the pre- post administration. 
Table (5) Compering the motivation scale results of the experimental group on the prepost administration

\begin{tabular}{|c|c|c|c|c|c|c|c|}
\hline \multirow{2}{*}{ Variable } & \multicolumn{2}{|c|}{$\begin{array}{c}\text { Experimental } \\
\text { group Pre }\end{array}$} & \multicolumn{2}{c|}{$\begin{array}{c}\text { experimental } \\
\text { group Post }\end{array}$} & \multirow{2}{*}{ T-value } & Sign. & \multirow{2}{*}{ Eta2 } \\
\cline { 2 - 6 } & mean & Std. Devi. & mean & Std. Devi. & & & \\
\hline Motivation & 56.68 & 3.63 & 76.59 & 3.68 & 25.12 & 0.001 & 0.95 \\
\hline
\end{tabular}

According to Table (5) reveals that there is a statistically significant difference between the mean score of the participants of experimental group on the pre and Postadministration of motivation scale at 0.001 level in favor of Post-administration. Statistics show that the mean scores are 56.6 and 76.6 and $t$ value is 25.1. These results mean that the experimental group is highly motivated in post adiminstration of the motivation scale compared to the pre administration.

Results indicated a large effect of the program on the experimental group motivation used in the overall scale score $($ eta2 $=0.9)$

\section{Recommendations}

Based on the findings and conclusions of this study, some practical recommendations are presented to meet the concerns of English teachers, course designers, and Ministry of Education

1- Using collaborative websites should be an essential tool for developing reading and writing ability.
2- Reading and writing should be taught through new technologies which attract students to read and write.

3- Reading and writing should be given more attention in preparatory schools.

4- Integrating technology in teaching language is a necessity.

5- Course designers should integrate activities which enable students to use the internet.

6- The Ministry of Education should provide teachers with the opportunity to familiarize themselves with various technology applications, share ideas and collaborate with each other on new technology projects and uses.

7- The Ministry of Education should provide schools with adequate, reliable and modern technologies and technical infrastructure that support effective teaching and learning. 


\section{Recommendations for further studies:} In order to extend the findings of this study, the researcher recommended the following:

1. Investigating the effectiveness of using online collaboration technology on other language skills (listening and speaking).

2. Investigating the effectiveness of using online collaboration on different levels of EFL learners such as high school students and education college students.

3. Investigating the effectiveness of using online collaboration on developing positive attitudes towards other EFL skills.

4. Finally, the researcher suggested further studies to investigate the effect of using other web 2.0 and web 3.0 tools such as blogs on developing students' reading and writing skills.

\section{References}

Jackendoff, R (2003)Foundations of Language: Brain, Meaning, Grammar, Evolution. Oxford University Press,

Cooper, J. D., \& Kiger, N. D. (2009). $\begin{array}{lll}\text { Literacy: Helping } & \text { students } \\ \text { construct } & \text { meaning. } & \text { Boston: }\end{array}$ Houghton Mifflin.
Küçük, S. (2007). Written expression and creativity. Samsun: The University Press

Raguseo,C.(2009) Building communicative classroom online. https://www.slideshare.net/CarlaR /towards-elearning-20-in-elt

Mackey, T. P. (2007). The social informatics of blog and wiki communities: Authoring communities of practice (CoPs). Retrieved Feb. 9, 2017http://www.caisacsi.ca/searc h.asp?vear $=2007$

Dawson, S. (2008). A study of the relationship between student social networks and sense of community.

Educational Technology\& Society, 11(3), 224-238.

Giesen, L. (2001). Activities for integrating reading and writing in the language classroom School for International Training. (M.A dissertation). Brattleboro, Vermont, USA

Sutter . A. (2007): Improving the Reading Skills of Emergent Spanish Readers through Writing, (published PH.D. dissertation), Curriculum and Instruction University of Wisconsin Oshkosh, Oshkosh, WI 54901-8621.

Durukan, E. (2011). Effects of cooperative integrated reading and composition (CIRC) technique on 
reading-writing

skills.

Educational Research and

Reviews, 6(1), 102-109

El-mashary,A. (2013 ) A suggested Strategy to develop Libyan Secondary Stage Student's Critical Reading and Writing Skills in the Light of the Language Experience Approach. (Unpublished M.A dissertation). Ain Shams University - Women's College.

Kemper, D., \& Meyer, V. (2015). Fusion: Integrated reading and writing. Canada: Cengage Learning.

Chen, Y. (2006). Using Children's Literature for Reading and Writing Stories. Asian EFL Journal, v8 n4 p.210-232

Gallagher,K.(2006).Teaching Adolescent Writers. Stenhouse

Publishers. ,Library of congress

Shelly, G. B., \& Frydenberg, M. (2009). Web 2.0: Concepts and applications. Mason, OH: SouthWestern.

Tsai, Jui-min. (2006). Connecting Reading and Writing in College EFL Courses. The InternetTESL Journal, XII(12). [Online] Available: http://iteslj.org/
Guilloteaux, M., \& Dörnyei, Z. (2009). Motivating language learners: A classroom-oriented investigation of the effects of motivational strategies on student motivation. TESOL Quarterly, 42(1), 55-77. doi:10.1002/j.15457249.2008.tb00207.x

Bunn, M. (2011). How to read like a writer. In

Hidi,S.,\& Boscolo,P. (2007)Writing and Motivation. Emerlad Group Publishing Limited .UK

Bahous, R., Bacha, N., Mona, N., (2011). Motivating students in the EFLclassroom: A case study of perspectives. English Language Teaching, 4(3). Retrieved Jan. 9, 2017

http://ccsenet.org/journal/index.ph $\mathrm{p} / \mathrm{elt} /$ article/view/11873

Fritz,M(2005) Students Using Handheld Computers to Learn Collaboratively in a First Grade Classroom. (published PH.D. dissertation) Drexel University.

Duffy and Bruns (2006) Educational Benefits of Wiki, 'Wiki'ed Awesome Classroom Technology ,Retrieved March,23rd ,2017 from https://sites.google.com/site/wikie dworld/current-research 